\title{
Enhancer variants: evaluating functions in common disease
}

\author{
Olivia Corradin ${ }^{1}$ and Peter C Scacheri ${ }^{1,2^{*}}$
}

\begin{abstract}
Gene enhancer elements are noncoding segments of DNA that play a central role in regulating transcriptional programs that control development, cell identity, and evolutionary processes. Recent studies have shown that noncoding single nucleotide polymorphisms (SNPs) that have been associated with risk for numerous common diseases through genome-wide association studies frequently lie in cell-type-specific enhancer elements. These enhancer variants probably influence transcriptional output, thereby offering a mechanistic basis to explain their association with risk for many common diseases. This review focuses on the identification and interpretation of disease-susceptibility variants that influence enhancer function. We discuss strategies for prioritizing the study of functional enhancer SNPs over those likely to be benign, review experimental and computational approaches to identifying the gene targets of enhancer variants, and highlight efforts to quantify the impact of enhancer variants on target transcript levels and cellular phenotypes. These studies are beginning to provide insights into the mechanistic basis of many common diseases, as well as into how we might translate this knowledge for improved disease diagnosis, prevention and treatments. Finally, we highlight five major challenges often associated with interpreting enhancer variants, and discuss recent technical advances that may help to surmount these challenges.
\end{abstract}

\section{Introduction}

Transcriptional enhancer elements are noncoding stretches of DNA that have a central role in controlling gene expression programs in cells. Rather than on-off switches, enhancers are hypothesized to function as transcriptional rheostats to fine-tune target transcript levels. Higher-order

\footnotetext{
* Correspondence: pxs183@case.edu
'Department of Genetics and Genome Sciences, Case Western Reserve

'Department of Genetics and Genome Sciences, Case Western Reserve University, Cleveland, $\mathrm{OH}$ 44122, USA

${ }^{2}$ Case Comprehensive Cancer Center, Case Western Reserve University, Cleveland, OH 44106, USA
}

three-dimensional organization of chromatin facilitates physical interactions between enhancers and their target promoters. Interactions between enhancers and their targets may occur on the same chromosome (in cis) or on different chromosomes (in trans) (Figure 1) [1-3]. In any given mammalian cell type, the number of putative enhancer elements ranges from 50,000 to 100,000, and therefore far exceeds the number of protein-coding genes.

In the last decade, more than 1,900 genome-wide association studies (GWASs) have been published, identifying loci associated with susceptibility to over 1,000 unique traits and common diseases [4]. With the eventual goal of finding new therapies and preventative measures for common diseases, efforts are now focused on determining the functional underpinnings of these associations. Several groups have associated GWAS risk variants, mostly SNPs, with newly annotated cell-type-specific gene enhancer elements identified through epigenomic profiling studies. These enhancer variants probably play an important part in common disease susceptibility by influencing transcriptional output. Of all the genetic risk variants discovered to date, the number that impact enhancer function is estimated to far exceed the number that affect protein-coding genes or disrupt promoter function (Figure 2). Additionally, disease-associated variants in noncoding regions, particularly those that lie in cell-type-specific enhancer elements, have been estimated to explain a greater proportion of the heritability for some disorders than variants in coding regions [5]. This review focuses on the identification and interpretation of disease-associated variants that affect enhancer function. We consider the latest approaches for evaluating enhancer variants and identifying their gene targets, and highlight successful cases in which risk variants have been shown to alter gene expression by disrupting enhancer function. In addition, we discuss the remaining challenges to delineating the impact of noncoding variants, such as the identification of enhancer activity, validation of causal variants and identification of responsible genes. Future efforts to surmount these challenges should help to remove the barrier between the discovery of disease 


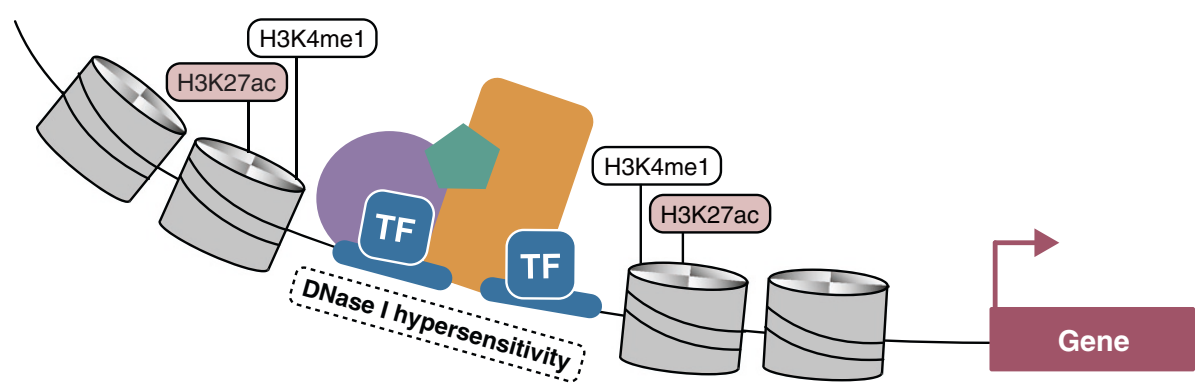

Figure 1 Model of enhancer function. Transcriptional enhancer elements are noncoding stretches of DNA that regulate gene expression levels, most often in cis. Active enhancer elements are located in open chromatin sensitive to DNase I digestion and flanked by histones marked with H3K4me1 and H3K27ac. Enhancers are often bound by a number of transcription factors (TF), such as p300 (blue). Mediator and cohesin are part of a complex (orange, green and purple) that mediates physical contacts between enhancers and their target promoters.

associations and the translation of this knowledge for improved diagnosis and treatment of many common diseases.

\section{Genetic risk variants are enriched in cell-type- specific enhancer elements defined by signature chromatin features}

The locations of enhancer elements coincide with DNase I hypersensitive regions of open chromatin flanked by nucleosomes marked with the mono- and/or di-methylated forms of lysine 4 at histone H3 (H3K4me1/2) [9,10]. Enhancers can be active or repressed, and each state generally correlates with the presence of additional histone marks, such as H3K27ac and H4K16ac which are associated with active chromatin, or H3K27me3 and H3K9me3 which are associated with repressed chromatin [11-14]. Active enhancers are bi-directionally transcribed and capped at their $5^{\prime}$ end $[15,16]$. Most enhancer elements are located in introns and intergenic regions, although some are exonic [17-19]. Relative to promoters, the distribution of enhancers across the epigenome is highly cell-type specific. Some of the first studies to associate GWAS variants with enhancer elements integrated genetic risk variants with regulatory element maps generated through epigenomic profiling (using chromatin immunoprecipitation combined with massively parallel DNA sequencing (ChIP-seq) and the profiling of DNase I hypersensitive sites (DHSs)) [20-22]. Two major themes emerged from these studies. First, loci with signature enhancer features (DHSs, H3K4me1, H3K27ac) are highly enriched for genetic risk variants relative to other chromatin-defined elements such as promoters and insulators [21]. Second, risk variants preferentially map to enhancers specific to disease-relevant cell types in both cancer and other common diseases [21]. For example, type 2 diabetes-associated variants preferentially map to pancreatic islet enhancers [22-25], and SNPs predisposing to colon cancer are enriched in enhancer elements in colon cancer cells and colon crypts, from which colon cancer is derived [26]. Further assessment of the effects of enhancer risk variants has shown that they can alter transcription-factor-binding sites (TFBSs) and impact the affinity of transcription factors for chromatin, and/or induce allele-specific effects on target gene expression [6,27-40]. These studies illustrate the utility of epigenomic profiling for identifying risk variants that lie in putative enhancer elements and for identifying disease-relevant cell types in which the enhancer variants could exert their regulatory effects.

\section{Super-enhancers, stretch enhancers, and enhancer clusters: hotspots for genetic risk variants}

Four studies recently demonstrated correlations between genetic risk variants and large clusters of active enhancers, similar to locus control regions. These features have been called 'super-enhancers' [41,42], 'stretch enhancers' [24], 'multiple enhancers' [7] and 'enhancer clusters' [23], and are similar but not identical between studies, although many of these features overlap. The methods used to identify these clusters are distinct. Super-enhancers, for example, are defined by identifying the top-ranking enhancers on the basis of the levels of associated transcription factors or chromatin marks identified through ChIP studies. Stretch enhancers are defined by stretches of open chromatin more densely and more broadly marked with enhancer-histone modifications than typical enhancers. Despite these differences, many of the defined features overlap. These enhancer clusters are highly cell-type specific and have been proposed to play a predominant role in regulating the cell-type-specific processes that define the biology of a given cell type. Moreover, they are disproportionally enriched for genetic risk variants compared to typical enhancers, and the enrichment is biased toward disease-relevant cell types. These results further support the notion that variants that influence cell-type-specific gene regulation are major contributors to common disease risk, and extend this concept to demonstrate that altering the expression of genes under exquisite regulation can frequently lead to increased risk. Enhancer cluster 


\section{(a) Distribution of GWAS variants}

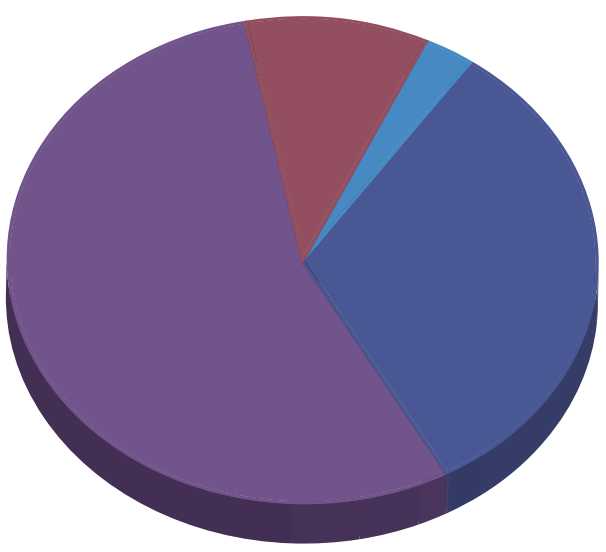

\section{Coding}

Promoter

Non-coding: intragenic

\section{Non-coding: intragenic}
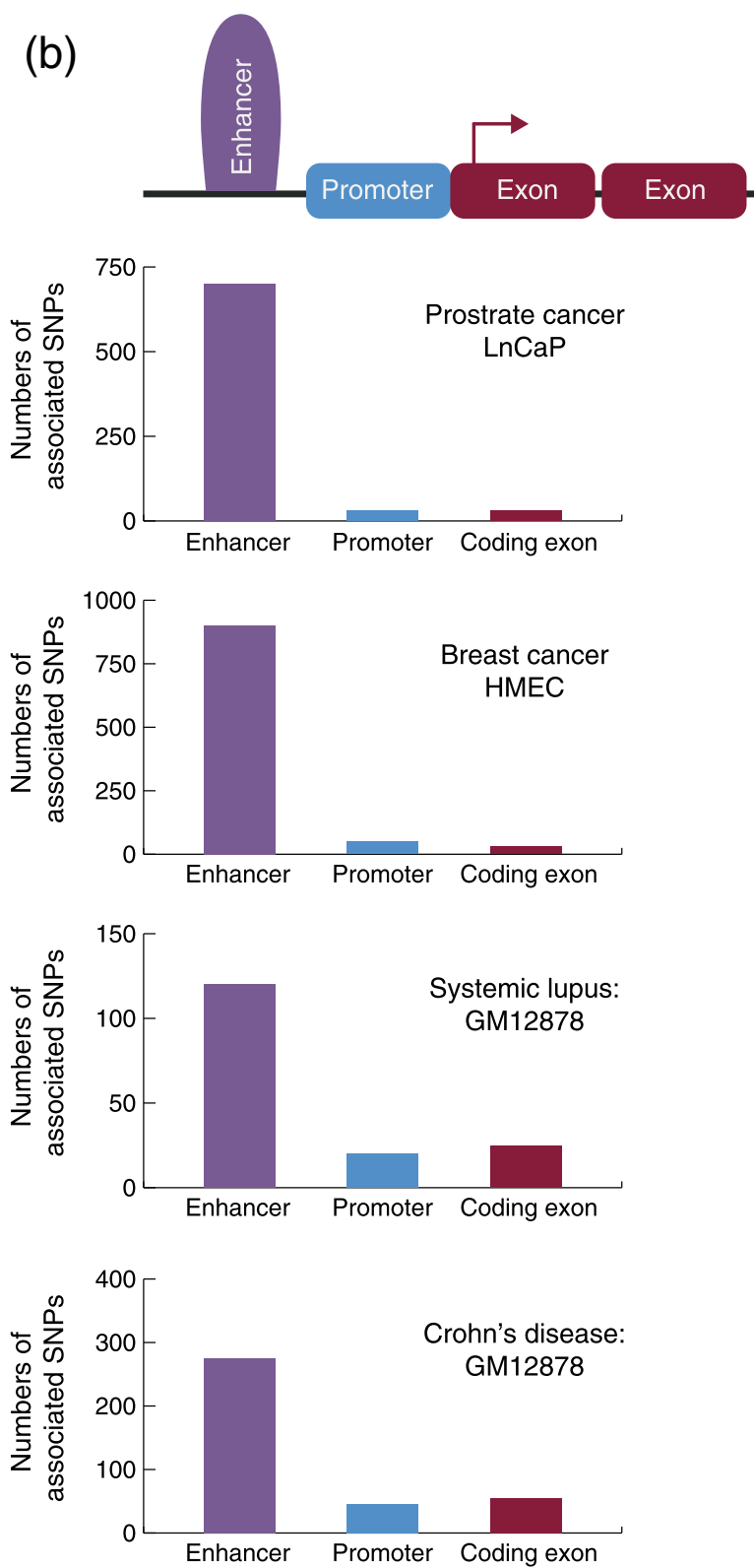

Figure 2 Enrichment of genome-wide association study variants in putative enhancer elements. (a) Number of disease-associated variants (identified in the National Human Genome Resource Institute's genome-wide association study (GWAS) catalog) that lie in protein-coding regions (red), promoters (blue), noncoding intragenic regions (light purple) and noncoding intergenic regions (dark purple). (b) Examples of four different common diseases, showing the number of associated single nucleotide polymorphisms (SNPs) that lie in putative enhancers, promoters and exons [6-8]. Putative enhancer elements were defined by chromatin features in each of the four indicated cell types.

identification provides a means of detecting highly regulated genes and may help to prioritize noncoding variants that are likely to be functional.

A typical locus identified through a GWAS contains dozens to thousands of SNPs in linkage disequilibrium (LD) with the 'lead' SNP that is reported to be associated with the disease in question. Any SNP in LD with the lead SNP may be causal, and the prevailing assumption is that only one is causal. Indeed, this scenario has been reported to be the case for some risk loci involving enhancers $[34,43]$, and there are several examples of Mendelian disorders in which a single enhancer variant causes congenital disease [44-50]. However, it is equally plausible that more than one SNP is causal, particularly at GWAS loci harboring enhancer clusters. In these instances, several variants distributed among multiple enhancers throughout the locus, rather than a single SNP, may combine to affect expression of their gene targets and confer susceptibility 
to common traits. This has been called the 'multiple enhancer variant' (MEV) hypothesis. Corradin and colleagues provided support for the MEV hypothesis for six common autoimmune disorders, including rheumatoid arthritis, Crohn's disease, celiac disease, multiple sclerosis, systemic lupus erythematosus and ulcerative colitis. The extent of MEVs across additional common diseases is not yet known [7,28,37].

\section{Interpreting enhancer variants}

Given that risk variants lie in cell-type-specific enhancer elements, it is critical to utilize a disease-relevant cell type to identify potential enhancer variants. SNPs associated with a particular disease can be compared to enhancer elements to identify cell types whose active enhancers are disproportionately enriched for disease variants. Variant set enrichment is a permutation-based method that compares the enrichment of genetic risk-variant sets within any functional element (such as H3K4me1-marked putative enhancers) to randomly generated matched genetic risk-variant sets [26,38]. This type of analysis provides an unbiased way of evaluating the utility of a cell type for studying the impact of variants on enhancer elements.

Several computational programs are currently available to integrate chromatin landscapes with GWAS risk variants to identify candidate regulatory SNPs and evaluate their disease-causing potential. These include IGR [38], RegulomeDB [51], HaploReg [52], FunciSNP [53] and FunSeq [54]. These programs are particularly useful for prioritizing SNPs for functional analyses, which may include transcription factor ChIP or electrophoretic mobility shift assays to test whether a given SNP influences a transcription factor's ability to bind to the enhancer, and in vitro and in vivo gene reporter assays to test the SNP's effect on enhancer activity. Additionally, allele-specific expression can be utilized to quantify the impact of enhancer variants within a specific cell type. Finally, DNA editing strategies involving CRISPR/Cas9-based methods can be employed to evaluate the effect of a variant. Following the identification of a functional enhancer variant, the next major challenge is to identify its target and to test the effect of the SNP(s) on target transcript levels. Many enhancer elements are located within 100 kilobases $(\mathrm{kb})$ of the genes that they regulate, but can also be located more than a megabase away, or even on separate chromosomes. Enhancers can regulate genes or long noncoding RNAs. Most genes are regulated by more than one enhancer, and many enhancers regulate more than one target gene $[55,56]$. The problem is further complicated by our limited knowledge of barrier elements, which block enhancer-gene interactions. The most common method of assigning an enhancer to its nearest gene is inaccurate, with false discovery rate (FDR) estimates ranging from $40 \%$ to $73 \%$ [55,57]. Refining methods for identifying the nearest gene to looking for the 'nearest expressed gene' still results in a high FDR, with $53 \%$ to $77 \%[55,58]$ of distal elements bypassing the nearest active transcription start site to interact with a distant gene. Clearly, proximity alone cannot be used to accurately identify the target of an enhancer SNP.

\section{Methods of identifying gene targets of enhancer variants}

To identity enhancer targets, DNA fluorescence in situ hybridization (FISH) [59,60], as well as chromatin association methods (chromosome conformation capture (3C)) [61], can be employed. These are powerful approaches for evaluating whether a region of interest interacts with a specific genomic target, but they suffer from the limitation that the regions of interest must be pre-specified, that is, they are 'one-by-one' approaches. 4C (circular chromosome conformation capture), an extension of $3 \mathrm{C}$, can capture all regions that physically contact a site of interest, without prior knowledge of the regions that contact that site being necessary [62] (that is, a 'one-to-all' approach). Higher-throughput methods include carbon-copy chromosome conformation capture (5C, many-to-many), a high-throughput expansion of 3C, Hi-C (all-to-all) and chromatin interaction analysis by paired-end tag sequencing (ChIA-PET) (for detailed comparison of these methods, see reviews $[63,64])$. These global approaches can enable the identification of loci that directly and indirectly contact enhancers of interest, and can reveal complex interactions in which dozens to hundreds of loci aggregate, so-called transcriptional hubs or enhanceosomes [65]. These types of high-order interactions have been recently described by several studies $[55,56,58]$. The extent by which they overlap risk loci remains unexplored. Unfortunately, these approaches tend to be expensive and difficult for most labs to execute, and their resolution often prohibits their use for interrogating GWAS loci. Until recently, for example, the resolution of $\mathrm{Hi}-\mathrm{C}$ was limited to capturing interactions separated by more than one megabase; 5 to 10 times greater than the distance by which most enhancer-gene interactions occur. Despite the limitations, 'C'-based methods have been implemented to successfully identify targets of enhancer-risk variants and to quantify their functional effects. For example, CowperSal lari and colleagues utilized $3 \mathrm{C}$ and allele-specific expression to demonstrate the impact of the breast cancer risk SNP rs4784227 on expression of TOX3, thought to have a role in chromatin regulation [38]. Bauer and coworkers utilized $3 C$ to identify $B C L 11 A$ as the gene target of an erythroid enhancer, and then further demonstrated the impact of enhancer variants on transcription factor binding and expression. Gene editing strategies have also been employed to demonstrate that this enhancer is essential for erythroid gene expression [28]. Finally, we highlight 
a study by Smemo and colleagues in which $4 \mathrm{C}$-seq was used to identify IRX3 as the target of an enhancer SNP located in intron 1 of the FTO gene, which was originally thought to be the target and therefore the causal gene for increased risk of obesity. Functional studies in mice were used to verify that IRX3 is the most likely causal gene, not FTO [30].

\section{Computational approaches to identify gene targets of enhancer elements}

As alternatives to experimental approaches, several groups have developed computational techniques for determining the targets of enhancers [7,16,21,66-70]. These methods are similar in that they compare patterns of regulatory activity across multiple cell types to predict interactions between enhancers and genes. However, they vary significantly in the type of data required to generate enhancergene predictions, the specific approaches used to generate and validate the predictions, and their availability (Table 1 ). The method described by Ernst and colleagues identifies H3K4me1/2 and H3K27ac sites that co-vary with expressed genes within $125 \mathrm{~kb}$ of the gene locus, and uses this to predict enhancer-gene interactions [21]. Thurman and coworkers utilized DHS exclusively to predict interactions. Enhancers were assigned to genes by correlating the crosscell-type DNase I signal at each DHS site with all promoters located within $500 \mathrm{~kb}$ [66]. The method developed by Sheffield and colleagues also uses DHS profiles, but additionally incorporates genome-wide expression data [70]. Rather than employing a fixed distance-based model, Shen and colleagues apply chromatin conformation data from $\mathrm{Hi}-\mathrm{C}$ experiments to guide the association of enhancers to genes marked by H3K4me1, H3K27ac and RNA Pol II [67]. As an alternative to methods based on chromatin structure, Andersson and colleagues leverage cap analysis of gene expression (CAGE) data to correlate transcription at enhancers with gene expression [16]. There are two computational approaches that are publicly available and executable through website or command-line programs: predicting specific tissue interactions of genes and enhancers (PreSTIGE) [7] and integrated methods for predicting enhancer targets (IM-PET) [69]. PreSTIGE identifies enhancers and genes that demonstrate quantitative celltype specificity based on $\mathrm{H} 3 \mathrm{~K} 4 \mathrm{me} 1$ and RNA sequencing (RNA-seq), and can process data from human and mouse cell types [68]. IM-PET, like previously discussed methods, considers the proximity of an enhancer to potential gene targets and the correlation of enhancer and promoter activity, along with measures of transcription factor activity and evolutionary conservation.

When the appropriate datasets are available, computational approaches can offer a relatively fast and costeffective way of identifying putative enhancer-gene interactions in a given cell type. However, they are generally limited to detecting a subset of enhancer-promoter interactions within a given cell type, and none are capable of identifying trans interactions. Methods that rely on celltype specificity or concordant changes in enhancers and genes across cell types may lack the sensitivity to predict interactions for ubiquitously expressed genes or to delineate interactions in domains with a high density of celltype-specific genes. There is no standard or 'reference' dataset to validate the accuracy of gene-enhancer predictions. Thus, each study utilizes a different approach to evaluate accuracy, which makes it difficult to determine which method is most accurate. This necessitates experimental validation of enhancer-gene interactions determined using prediction-based methods. Despite these limitations, computational approaches can help to identify the targets of enhancer-risk variants. The method developed by Thurman and colleagues was applied to all GWAS loci and predicted gene targets of 419 diseaseassociated risk variants [20], most of which were located more than $100 \mathrm{~kb}$ from the risk SNP. PreSTIGE was utilized to predict gene targets of 122 noncoding loci associated with six immune disorders: rheumatoid arthritis, Crohn's disease, celiac disease, multiple sclerosis, lupus and ulcerative colitis. Furthermore, at several of the autoimmune-disease-associated loci, the effect of the risk allele on target gene expression was quantified.

\section{Utilizing expression quantitative trait loci studies to evaluate the impact of enhancer variants}

Expression quantitative trait loci (eQTL) studies enable the identification of genetic variants that influence gene expression. eQTL studies involve stratifying a panel of individuals based on their particular SNP genotypes and then determining whether transcript levels differ between individuals based on the specific SNP genotypes. Genomewide eQTL studies have identified transcripts that differ in expression on the basis of the genotype of the risk allele at GWAS loci. Alternatively, eQTL-based analyses can be applied to candidate interactions between SNPs and gene targets identified through the experimental or computational approaches described above. In both instances, genetic variation inherent in the human population is utilized to reveal the quantitative and directional effect of SNPs on gene expression (that is, the degree to which expression is upregulated or downregulated).

eQTL studies can locate SNPs within a given GWAS locus that influence target transcript levels, but caution must be taken when interpreting results. First, eQTLs, like enhancers, are cell-type specific. Thus, the effect of a SNP on transcription may only occur in disease-relevant cell types [71,72]. Second, the SNP associated with transcript levels may not be the causal SNP: SNPs in LD with the eQTL SNP may be driving the association. Third, the results are correlative and may reflect indirect associations 
Table 1 Computational approaches to predicting gene targets of enhancer elements

\begin{tabular}{|c|c|c|c|c|c|c|c|}
\hline Reference or method & Input data required & $\begin{array}{l}\text { Gene } \\
\text { expression }\end{array}$ & Linear model & $\begin{array}{l}\text { Number of genes } \\
\text { with predictions } \\
\text { (per cell line) }\end{array}$ & FDR & Species & Publically available \\
\hline Nearest gene & None & Not considered & Nearest gene & NA & $\sim 40 \%$ to $73 \%$ & Any & NA \\
\hline Nearest expressed gene & Gene expression & Considered & Nearest expressed gene & NA & $\sim 53 \%$ to $77 \%$ & Any & NA \\
\hline Ernst et al. [21] & $\begin{array}{l}\text { H3K4me1, H3K4me2, } \\
\text { H3K27ac, RNA-seq }\end{array}$ & Considered & Distance based (125 kb) & NA & Not determined & Human & No \\
\hline Thurman et al. [66] & DNase I hypersensitivity & Not considered & Distance based (500 kb) & NA & Not determined & Human & No \\
\hline Sheffield et al. [70] & $\begin{array}{l}\text { DNase I hypersensitivity } \\
\text { and RNA-seq }\end{array}$ & Considered & $100 \mathrm{~kb}$ & NA & Not determined & Human & Predicted interactions: [http://dnase.genome.duke.edu/] \\
\hline Shen et al. [67] & $\begin{array}{l}\text { H3K4me1, H3K27ac, RNA } \\
\text { Pol II }\end{array}$ & Not considered & $\begin{array}{l}\text { Topological domain } \\
\text { based }\end{array}$ & 5,000 to 8,000 & Not determined & Mouse & No \\
\hline Andersson et al. [16] & CAGE & Considered & $500 \mathrm{~kb}$ & NA & Not determined & Human & No \\
\hline PrestigE [7] & H3K4me1 & Considered & $\begin{array}{l}\text { Distance (100 kb) } \\
\text { and CTCF based }\end{array}$ & 3,000 to 5,000 & $\sim 13 \%$ to $23 \%$ & Human & $\begin{array}{l}\text { Predicted interactions: http://genetics.case.edu/prestige } \\
\text { Method application: http://prestige.case.edu }\end{array}$ \\
\hline PreSTIGEouse [68] & H3K4me1 & Considered & Distance based (100 kb) & 3,000 to 5,000 & Not determined & Mouse & $\begin{array}{l}\text { Predicted interactions: http://genetics.case.edu/prestige } \\
\text { Method application: http://prestige.case.edu }\end{array}$ \\
\hline IM-PET [69] & $\begin{array}{l}\text { H3K4me1, H3K27ac, } \\
\text { H3K4me3 and RNA-seq* }\end{array}$ & Considered & Distance (2 Mb) & 7,000 to 10,000 & $\sim 1 \%$ & Human & $\begin{array}{l}\text { Method application: http://www.healthcare.uiowa.edu/ } \\
\text { labs/tan/IM-PET.html }\end{array}$ \\
\hline
\end{tabular}

$\mathrm{Mb}$, megabases; NA, not applicable; RNA-seq, RNA sequencing. 
between SNPs and genes. Fourth, the effects on gene expression must be robust in order to be identified over the confounding effects of the genetic background. This poses a challenge for detecting functional variants that have modest effects, as has been proposed for most enhancer variants $[7,33,73,74]$. Fifth, eQTL analyses rarely consider the combinatorial effects of multiple SNPs at a given locus. Last, because eQTL studies are typically performed on healthy individuals, the impact of the SNP on the quantitative trait may differ in response to disease-specific stimuli. This was observed in a survey of enhancer SNPs associated with prostate cancer. Here, the effect of a SNP on enhancer function was only observed in the presence of the androgen dihydrotestosterone [6]. Additionally, a study by Harismendy and co-workers demonstrated that the chromatin interaction between an enhancer locus associated with coronary artery disease and the gene target IFNA21 was significantly remodeled by treatment with interferon- $\gamma[31]$.

\section{Transcriptional effects of enhancer variants}

Studies that delineate the impact of disease-associated enhancer variants (Table 2) reveal the relatively modest effect of enhancer variants on gene expression. The effect of enhancer variants has also been evaluated with massively parallel reporter assays in which the impact of mutations in enhancer sequences is determined through heterologous barcoding and high-throughput sequencing (reviewed in [75]). These high-throughput assays show that most variants that impact transcription induce 1.3- to 2-fold differences in target gene expression [73,74]. These findings align with the notion that enhancers modulate or fine-tune gene expression, analogous to a rheostat. Despite their modest transcriptional effects, enhancer variants can have large effects on downstream phenotypes. As an example, we highlight a SNP (rs12821256) associated with blond hair color in Europeans. This SNP lies in an enhancer that drives KITLG expression in developing hair follicles [33]. The blond-hair-associated SNP was shown to reduce enhancer activity by only $22 \%$ in vitro. Nonetheless, when the blond hair and ancestral alleles were evaluated in transgenic mice, the reduction in enhancer activity associated with the blond hair allele was sufficient to yield mice of visibly lighter coat color than mice generated with the ancestral allele [33]. Whether or not the blond-hair-associated SNP represents a special instance of a more general mechanism in which enhancer variants with modest functional effects have robust phenotypic effects remains to be seen.

\section{Implications for disease and medicine}

The strategies discussed above (summarized in Figure 3) have been utilized to interpret the transcriptional effects of enhancer variants associated with several traits and common diseases. The continued application of these and other emerging strategies will have important implications for disease and medicine. These studies should not only help to reveal the gene targets of noncoding risk variants, but also provide information on whether these risk variants increase or decrease expression of the target gene. This information will be essential for identifying appropriate therapeutic targets and determining whether inhibitors or activators of these targets would be most effective. Knowledge of gene targets may also reveal pathways that are commonly altered among affected individuals, which could also guide treatment strategies and rational drug design.

\section{Conclusions and future challenges}

We have reviewed approaches for the identification and interpretation of common-disease-associated variants that impact enhancer function, citing examples in which these methods have been successfully implemented (Figure 3, Table 2). We highlight three main conclusions. First, celltype-specific enhancer variants are highly prevalent among loci associated with the majority of common diseases identified through GWASs. Second, GWAS-identified enhancer variants are disproportionally enriched in enhancer clusters, which control genes with highly specialized celltype-specific functions. Third, these enhancer variants can have modest but significant effects on target gene expression, which can have robust effects on phenotype. Thus, interpreting the functional effects of enhancer variants requires rational experiment design that takes these characteristics into account. Furthermore, although current methods have enabled the thorough characterization of enhancer variants at some GWAS loci, high-throughput methods are needed, given the huge number of diseaseassociated enhancer variants. Here, we discuss additional lessons learned from these studies, and note five remaining challenges (Figure 4).

First, chromatin landscapes vary considerably between cell types and are highly dynamic, capable of altering in response to internal and external environmental stimuli. Given the spacial, temporal, environmental and epigenetic complexity of gene regulation, it is essential that the appropriate human cell type or model is utilized when trying to draw inferences between risk alleles and enhancer elements. Integrating risk variants with the chromatin landscapes of cell types or conditions that are insufficient models for a disorder will likely give misleading results. This is highlighted by eQTL studies. Even in comparisons of relatively similar cell types (monocytes and T cells [72] or B cells and monocytes [71]), noncoding variants that impact expression in one cell type often had no effect in the other cell type. Additionally, in a study of cis-regulation in colon cancer, the impact of some SNPs on expression was seen amongst colon cancer samples, but not observed in normal colon from the same patients, implying 
Table 2 Functional enhancer studies of GWAS risk loci

\begin{tabular}{|c|c|c|c|c|c|c|c|}
\hline Disease/trait & Reference & Lead SNP & $\begin{array}{l}\text { Proposed } \\
\text { functional } \\
\text { SNP }\end{array}$ & Gene target & $\begin{array}{l}\text { How gene target } \\
\text { was selected }\end{array}$ & Cell type & Data supporting SNP enhancer function \\
\hline Blond hair color & Guenther et al. [33] & rs12821256 & rs12821256 & KITLG & $\begin{array}{l}\text { Phenotype in mouse } \\
\text { model }\end{array}$ & $\begin{array}{l}\text { Developing hair follicles, } \\
\text { HaCaT karatinocyte cell } \\
\text { line }\end{array}$ & $\begin{array}{l}\text { Allele-specific luciferase activity, allele-specific ChIP, effect } \\
\text { of SNP on mouse phenotype }\end{array}$ \\
\hline Breast cancer & $\begin{array}{l}\text { Cowper-Sal lari } \\
\text { et al. [38] }\end{array}$ & rs4784227 & rs4784227 & TOX3 & $3 C$ & MCF7 & $\begin{array}{l}\text { Binding motif disruption, allele-specific ChIP, allele-specific } \\
\text { 3C, allele-specific expression, eQTL }\end{array}$ \\
\hline $\begin{array}{l}\text { Colorectal } \\
\text { cancer }\end{array}$ & Pomerantz et al. [34] & rs6983267 & rs6983267 & $c-M Y C$ & $3 C$ & Colo205 and LS174T & Allele-specific luciferase activity, allele-specific ChIP \\
\hline $\begin{array}{l}\text { Colorectal } \\
\text { cancer }\end{array}$ & Wright et al. [39] & rs6983267 & rs6983267 & $c-M Y C$ & $3 C$ & DLD1 and HCT116 & Allele-specific ChIP, allele-specific expression \\
\hline $\begin{array}{l}\text { Colorectal } \\
\text { cancer }\end{array}$ & Tuupanen et al. [36] & rs67491583 & rs67491583 & $c-M Y C$ & Nearest gene & HeLa & $\begin{array}{l}\text { Binding motif disruption, allele-specific ChIP, allele-specific } \\
\text { luciferase activity }\end{array}$ \\
\hline Prostate cancer & Wasserman et al. [35] & rs6983267 & rs6983267 & $c-M Y C$ & Nearest gene & Prostate tissue (mouse) & Allele-specific activity, LacZ enhancer assay (mouse) \\
\hline $\begin{array}{l}\text { Coronary artery } \\
\text { disease }\end{array}$ & Harismendy et al. [31] & rs10757278 & $\begin{array}{l}\text { rs10811656/ } \\
\text { rs10757278 }\end{array}$ & $\begin{array}{l}\text { CDKN2B, } \\
\text { CDKN2BAS, } \\
\text { IFNA21, MTAP }\end{array}$ & $3 \mathrm{C}$ and FISH (IFNA21) & HUVEC & Binding motif disruption, allele-specific ChIP \\
\hline $\begin{array}{l}\text { Coronary heart } \\
\text { disease }\end{array}$ & Miller et al. [29] & rs12190287 & rs12190287 & TCF21 & $\begin{array}{l}\text { Nearest gene, eQTL } \\
\text { gene }\end{array}$ & HCASMC & $\begin{array}{l}\text { Binding motif disruption, allele-specific luciferase activity, } \\
\text { EMSA, allele-specific ChIP and allele-specific expression }\end{array}$ \\
\hline $\begin{array}{l}\text { Fetal hemoglobin } \\
\text { level }\end{array}$ & Bauer et al. [28] & $\begin{array}{l}\text { rs } 1427407 \\
\text { rs7606173 }\end{array}$ & $\begin{array}{l}\text { rs1427407, } \\
\text { rs7606173 }\end{array}$ & $B C L 11 A$ & $3 C$ & $\begin{array}{l}\text { Primary human } \\
\text { erythroblasts }\end{array}$ & $\begin{array}{l}\text { Binding motif disruption, allele-specific ChIP, allele-specific } \\
\text { expression, LacZ enhancer assay (mouse), deletion by TALEN }\end{array}$ \\
\hline $\begin{array}{l}\text { Multiple } \\
\text { sclerosis }\end{array}$ & Alcina et al. [27] & rs658115 & rs10877013 & $\begin{array}{l}\text { FAM119B, AVIL, } \\
\text { TSFM, TSPAN31 }\end{array}$ & eQTL & LCLs and monocytes & Allele-specific luciferase activity, eQTL \\
\hline Obesity & Smemo et al. [30] & rs9930506 & NA & $\operatorname{IRX} 3$ & $\begin{array}{l}\text { 4C-seq, 3C, ChIA-PET, } \\
\mathrm{Hi}-\mathrm{C}\end{array}$ & $\begin{array}{l}\text { Whole mouse embryo } \\
\text { and adult mouse brain }\end{array}$ & eQTL mapping \\
\hline Prostate cancer & Hazelett et al. [6] & rs5945619 & rs4907792 & NUDT1 & $\begin{array}{l}\text { Nearest gene, eQTL } \\
\text { gene }\end{array}$ & LNCaP & Allele-specific luciferase activity, eQTL \\
\hline Prostate cancer & Hazelett et al. [6] & rs10486567 & rs10486567 & $J A Z F 1$ & Nearest gene & LNCaP & Allele-specific luciferase activity, binding motif disruption \\
\hline QT interval & Kapoor et al. [32] & rs12143842 & rs7539120 & NOSIAP & $\begin{array}{l}\text { eQTL gene, genetic } \\
\text { association }\end{array}$ & Cardiac tissues & $\begin{array}{l}\text { Allele-specific luciferase activity, eQTL, enhancer assay } \\
\text { (zebrafish embryos) }\end{array}$ \\
\hline $\begin{array}{l}\text { Restless leg } \\
\text { syndrome }\end{array}$ & Spieler et al. [37] & rs12469063 & rs13469063 & MEISI & $\begin{array}{l}\text { PreSTIGE prediction } \\
\text { method, ChIA-PET, } \\
\text { Hi-C }\end{array}$ & Telencephalon & $\begin{array}{l}\text { Allele-specific expression of reporter gene in zebrafish, Allele- } \\
\text { specific LacZ (mouse), EMSA, binding motif disruption, effect } \\
\text { of decreased gene expression on phenotype }\end{array}$ \\
\hline $\begin{array}{l}\text { Systemic lupus } \\
\text { erythematosus }\end{array}$ & Wang et al. [40] & rs2230926 & $\begin{array}{l}\text { rs148314165, } \\
\text { rs200820567 }\end{array}$ & TNFAIP3 & $3 C$ & LCLs & EMSA, allele-specific luciferase activity, allele-specific $3 C$ \\
\hline Type 2 diabetes & Gaulton et al. [76] & rs7903146 & rs7903146 & TCF7L2 & Nearest gene & Pancreatic islet cells & Allele-specific luciferase activity, allele-specific FAIRE \\
\hline
\end{tabular}


Reporter assay

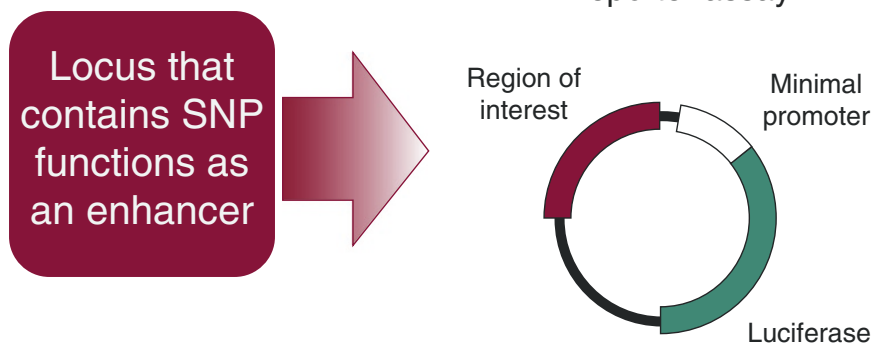

Massively parallel reporter assay

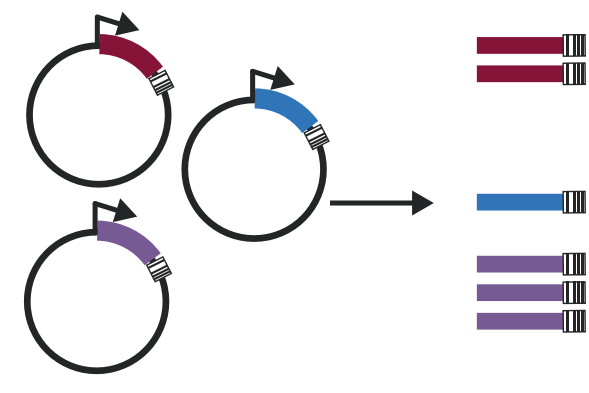

Computational predictions

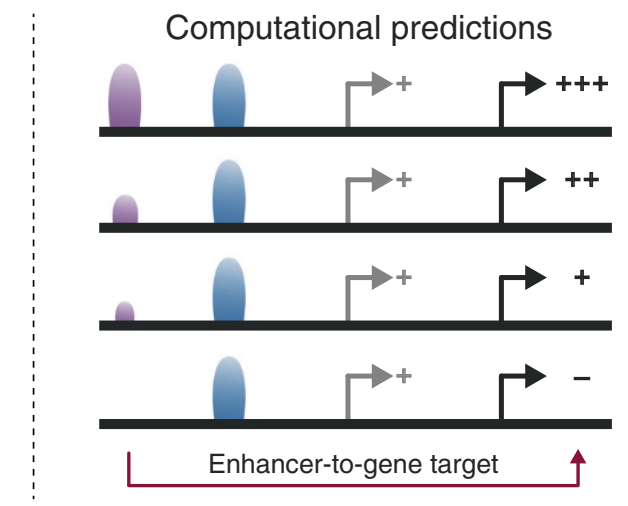

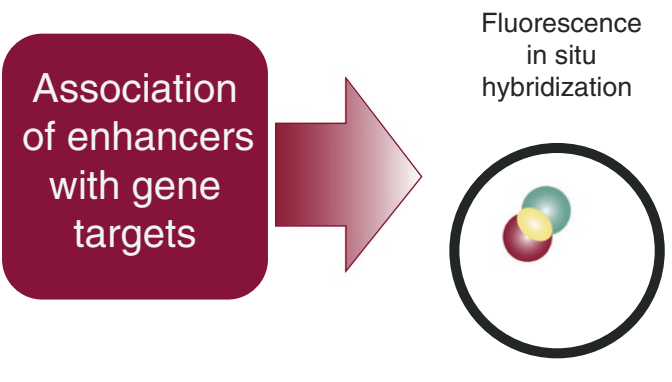

Chromosome conformation capture
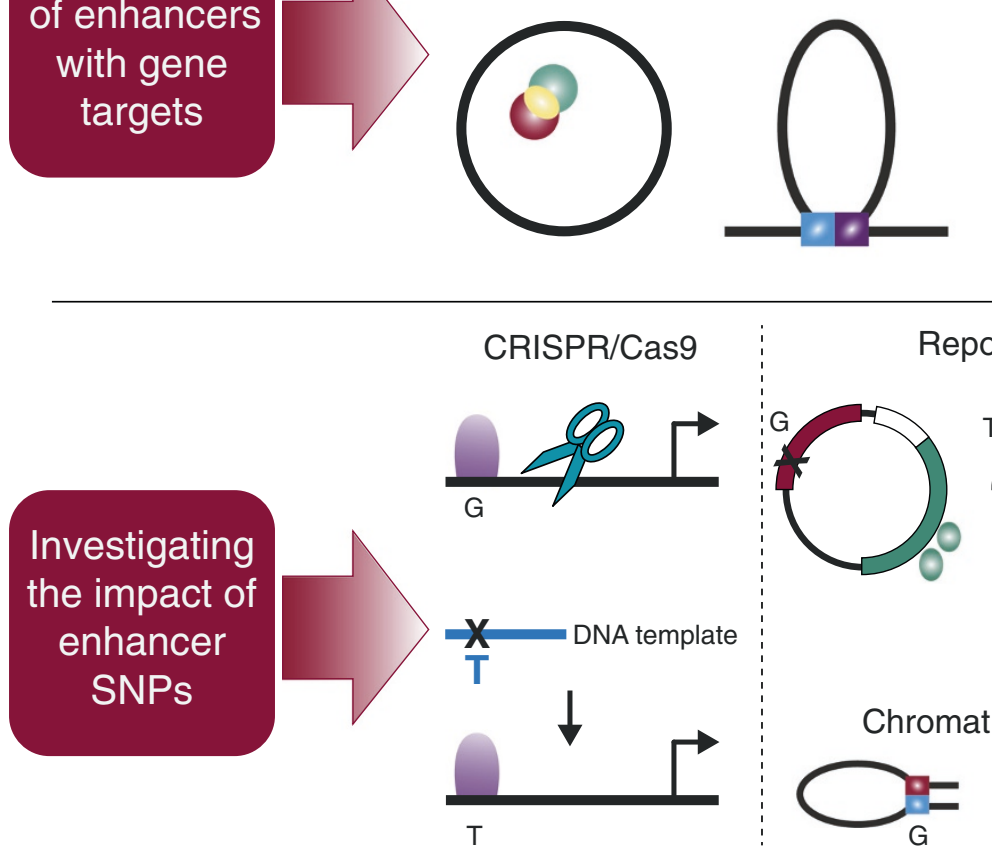

Reporter

Allele-specific binding

Figure 3 Interpreting enhancer variants. Various strategies for interpreting enhancer variants. (Top) Single- or high-throughput reporter assays can be used to test whether a putative enhancer is functional. (Middle) Gene targets of enhancers can be identified through experimental approaches such as fluorescence in situ hybridization and chromosome conformation capture assays, or through computational methods. (Bottom) The impact of a single nucleotide polymorphism (SNP) on enhancer function can be evaluated through CRISPR/Cas9-based DNA editing approaches, followed by measures of enhancer activity or target gene expression. The effect of a risk SNP on transcriptional activity and chromatin architecture can be evaluated through reporter assays and chromosome-conformation-capture-based experiments. Effects of the risk SNP on allele-specific expression and transcription factor binding can also be studied through quantitative ChIP and expression studies. Expression quantitative trait loci (eQTL) analysis can be performed to determine the effect of risk SNPs on gene expression levels.

that the impact of the variant is dependent on diseasespecific environmental factors [80]. The effect of noncoding variants on expression was also observed to be strongly context dependent in a study of monocytes under diverse types and durations of stimuli. Fairfax and colleagues demonstrated that $43 \%$ of identified eQTLs were associated with an effect on expression only after treatment with immune response stimuli lipopolysaccharide or interferon- $\gamma[81]$.

Second, there remains a gap between the prediction and functional validation of putative enhancer elements. Thus, if a risk SNP is localized to a putative enhancer 


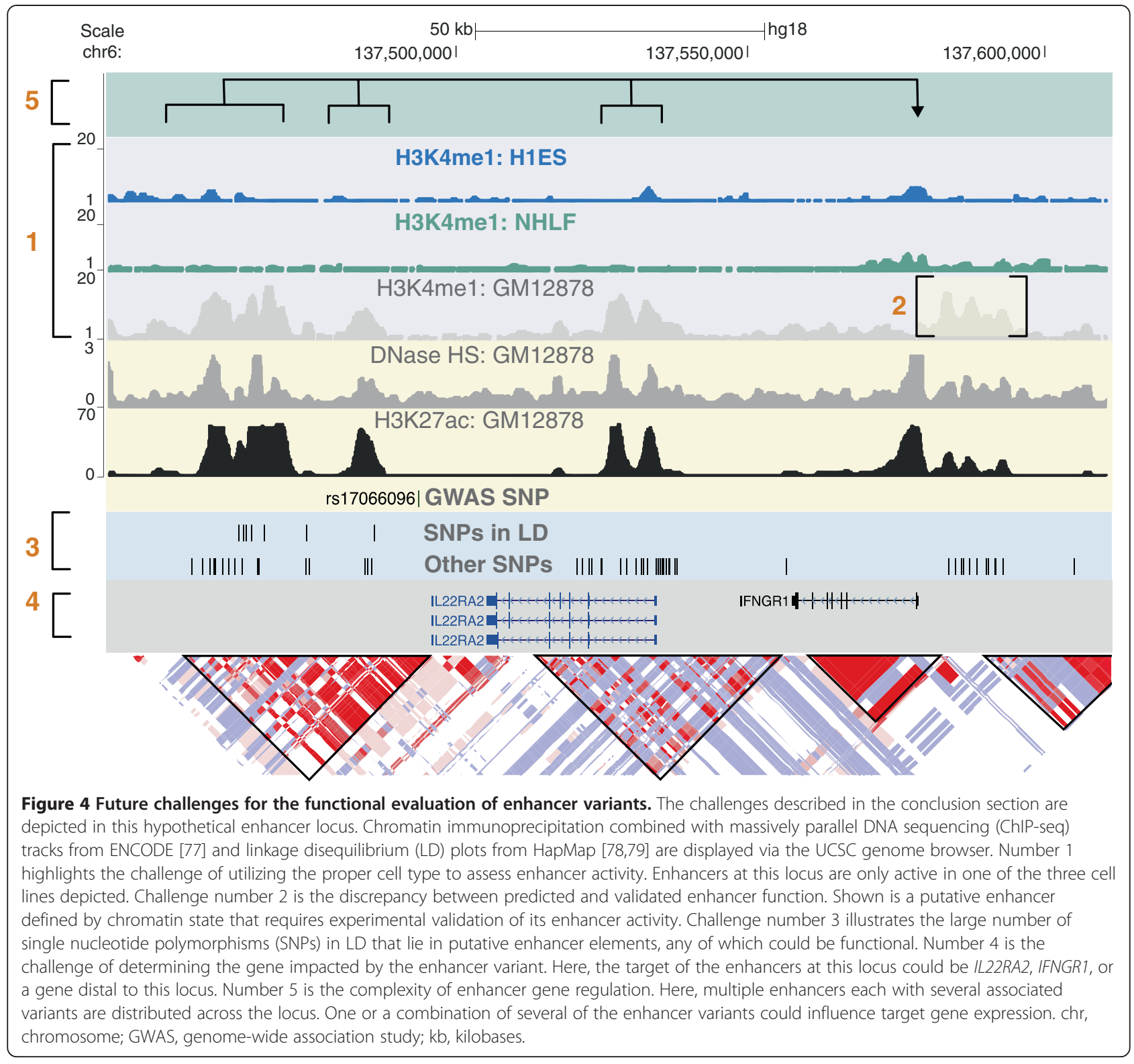

element defined through chromatin profiling, it is essential that the putative enhancer is functionally validated. In vitro and in vivo reporter assays can help in this regard. However, these assays are relatively low throughput and usually involve the use of a general promoter such as SV40 rather than the enhancer's endogenous promoter, which complicates the interpretation of negative results. Additionally, most genes are regulated by more than one enhancer, yet typically only one enhancer is tested in a reporter assay.

Third, at a given GWAS locus, the SNP with the most significant association (that is, the lowest $P$ value) with the disease is usually reported as the 'lead' SNP. Except in rare instances, such as the SNP rs6983267, which influences the MYC enhancer and confers risk for multiple cancers $[34,35]$, the SNP with the lowest $P$ value is not necessarily causal. Any SNP in LD with the lead SNP may be causal, and there may be dozens to thousands of candidates. Fine mapping studies can help narrow the locus and reduce the number of candidates. Additionally, as discussed above, identifying SNPs that co-localize with enhancer-chromatin features or TFBSs in an appropriate human cell type can help prioritize candidate functional variants $[30,38]$. Indeed, Claussnitzer and colleagues developed a method, phylogenetic module complexity analysis (PMCA), which utilizes conserved co-occurring TFBS patterns to identify functional regulatory variants [82]. However, hundreds of candidate SNPs may remain even after prioritization, especially when the locus harbors an enhancer cluster. This was 
illustrated in a recent survey of breast cancer risk loci, which showed that 921 SNPs co-localize with putative enhancers in human mammary epithelial cells across 71 risk loci [8]. Similarly, 663 enhancer SNPs were identified for 77 prostate risk loci [6]. Furthermore, while some enhancer variants influence transcription factor binding [6,28,29,34], SNPs do not necessarily have to reside within a TFBS to influence transcription factor binding or enhancer activity $[33,73,74,83]$. It is clear that massively parallel reporter assays (discussed above) will be necessary to help distinguish functional variants from those that are passengers.

Fourth, in order to determine the phenotypic effect of an enhancer variant, it is essential that an enhancer variant is demonstrated to influence the levels of its target transcript. The target may be a gene, or could alternatively be a noncoding RNA. However, enhancers frequently regulate multiple genes. Even if the levels of a given transcript correlate with the genotype of an enhancer risk variant, it does not necessarily mean that the correlated gene is causal. Functional assays, and ultimately in vivo models, are needed to verify that the gene is directly involved in the development of the disease. CRISPR/Cas9 technology would enable such studies by altering single SNPs in the genome of a model organism while maintaining the native genomic context of the variant. Alternatively, single-site integration of the risk or non-risk alleles into a model organism, as utilized for the enhancer variant associated with blond hair color [33], could be employed. Although CRISPR/Cas9 can be utilized to demonstrate the functional impact of a given variant, the complex phenotypes of many diseases are not easily modeled in vitro and thus the determination of causality will often not be trivial.

Lastly, genes are frequently regulated by multiple enhancer elements or clusters of enhancer elements. Thus, the independent effect of a single enhancer or variant may be below the sensitivity threshold of standard assays. This, in addition to the demonstration that multiple enhancer SNPs can act in combination to impact gene expression, suggests that epistatic effects between noncoding variants may play a particularly important role for enhancer loci, especially when enhancer variants of the same gene are inherited independently. The impact of the interaction between SNPs on transcription and ultimately on clinical risk for disease remains to be seen.

We have discussed the strategies for, and challenges associated with, the interpretation of noncoding putative enhancer SNPs as applied to the study of common variants identified by GWAS studies of common diseases and traits. As whole-genome sequencing becomes more prevalent, these same strategies will be necessary to elucidate the impact of rare noncoding mutations and to distinguish damaging from innocuous enhancer alterations.

\section{Abbreviations}

3C: Chromosome conformation capture; 4C: Circular chromosome conformation capture; 5C: Carbon-copy chromosome conformation capture; CAGE: Cap analysis of gene expression; ChIA-PET: Chromatin interaction analysis by paired-end tag sequencing; ChIP-seq: Chromatin immunoprecipitation with massively parallel DNA sequencing; DHS: DNase I hypersensitivity site; eQTL: Expression quantitative trait loci; FDR: False discovery rate; FISH: Fluorescence in situ hybridization; GWAS: Genome-wide association study; H3K27ac: Acetylation of lysine 27 on histone 3 [as an example]; H3K4me: Methylation of lysine 4 on histone 3 [as an example]; IM-PET: Integrated methods for predicting enhancer targets; kb: Kilobases; LD: Linkage disequilibrium; MEV: Multiple enhancer variant; PMCA: Phylogenetic module complexity analysis; PreSTIGE: Predicting specific tissue interactions of genes and enhancers; RNA-seq: RNA sequencing; SNP: Single nucleotide polymorphism; TFBS: Transcription-factor-binding site; VSE: Variant set enrichment

\section{Competing interests}

The authors declare that they have no competing interests.

\section{Acknowledgements}

This work was supported by NIH grants R01CA160356, R01DC009410, R01DE018470 (PCS) and CWRU Cellular and Molecular Biology training grant T32GM008056 (OC).

Published online: 28 October 2014

\section{References}

1. Sasaki-Iwaoka H, Maruyama K, Endoh H, Komori T, Kato S, Kawashima H: A trans-acting enhancer modulates estrogen-mediated transcription of reporter genes in osteoblasts. J Bone Miner Res 1999, 14:248-255.

2. Muller HP, Schaffner W: Transcriptional enhancer can act in trans. Trends Genet 1990, 6:300-304

3. Muller HP, Sogo JM, Schaffner W: An enhancer stimulates transcription in trans when attached to the promoter via a protein bridge. Cell 1989, 58:767-777.

4. A Catalog of Published Genome-Wide Association Studies. [http://www. genome.gov/gwasstudies]

5. Gusev A, Hong Lee S, Neale BM, Trynka G, Vilhjalmsson BJ, Finucane H, Xu H, Zang C, Ripka S, Stahl E, Schizophrenia Working Group of the PGC, SWE-SCZ Consortium, Kahler AK, Hultman CM, Purcell SM, McCarroll SA, Daly M, Pasaniuc B, Sullivan PF, Wray NR, Raychaudhuri S, Price AL: Regulatory variants explain much more heritability than coding variants across 11 common diseases. bioRxiv 2014, doi:10.1101/004309.

6. Hazelett DJ, Rhie SK, Gaddis M, Yan C, Lakeland DL, Coetzee SG, Henderson BE, Noushmehr H, Cozen W, Kote-Jarai Z, Eeles RA, Easton DF, Haiman CA, Lu W, Farnham PJ, Coetzee GA, Ellipse/GAME-ON consortium, Practical consortium: Comprehensive functional annotation of 77 prostate cancer risk loci. PLoS Genet 2014, 10:e1004102.

7. Corradin O, Saiakhova A, Akhtar-Zaidi B, Myeroff L, Willis J, Cowper-Sal lari R, Lupien M, Markowitz S, Scacheri PC: Combinatorial effects of multiple enhancer variants in linkage disequilibrium dictate levels of gene expression to confer susceptibility to common traits. Genome Res 2014, 24:1-13.

8. Rhie SK, Coetzee SG, Noushmehr H, Yan C, Kim JM, Haiman CA, Coetzee GA: Comprehensive functional annotation of seventy-one breast cancer risk loci. PLoS One 2013, 8:e63925.

9. Heintzman ND, Stuart RK, Hon G, Fu Y, Ching CW, Hawkins RD, Barrera LO, Van Calcar S, Qu C, Ching KA, Wang W, Weng Z, Green RD, Crawford GE, Ren B: Distinct and predictive chromatin signatures of transcriptional promoters and enhancers in the human genome. Nat Genet 2007, 39:311-318

10. Heintzman ND, Hon GC, Hawkins RD, Kheradpour P, Stark A, Harp LF, Ye Z, Lee LK, Stuart RK, Ching CW, Ching KA, Antosiewicz-Bourget JE, Liu H, Zhang X, Green RD, Lobanenkov W, Stewart R, Thomson JA, Crawford GE, Kellis M, Ren B: Histone modifications at human enhancers reflect global cell-type-specific gene expression. Nature 2009, 459:108-112.

11. Creyghton MP, Cheng AW, Welstead GG, Kooistra T, Carey BW, Steine EJ, Hanna J, Lodato MA, Frampton GM, Sharp PA, Boyer LA, Young RA, Jaenisch R: Histone H3K27ac separates active from poised enhancers and predicts developmental state. Proc Natl Acad Sci U S A 2010, 107:21931-21936. 
12. Rada-Iglesias A, Bajpai R, Swigut T, Brugmann SA, Flynn RA, Wysocka J: A unique chromatin signature uncovers early developmental enhancers in humans. Nature 2011, 470:279-283.

13. Zentner GE, Tesar PJ, Scacheri PC: Epigenetic signatures distinguish multiple classes of enhancers with distinct cellular functions. Genome Res 2011, 21:1273-1283.

14. Taylor GC, Eskeland R, Hekimoglu-Balkan B, Pradeepa MM, Bickmore WA: H4K16 acetylation marks active genes and enhancers of embryonic stem cells, but does not alter chromatin compaction. Genome Res 2013, 23:2053-2065

15. Kim TK, Hemberg M, Gray JM, Costa AM, Bear DM, Wu J, Harmin DA Laptewicz M, Barbara-Haley K, Kuersten S, Markenscoff-Papadimitriou E, Kuhl D, Bito H, Worley PF, Kreiman G, Greenberg ME: Widespread transcription at neuronal activity-regulated enhancers. Nature 2010, 465:182-187.

16. Andersson R, Gebhard C, Miguel-Escalada I, Hoof I, Bornholdt J, Boyd M, Chen Y, Zhao X, Schmidl C, Suzuki T, Ntini E, Arner E, Valen E, Li K, Schwarzfischer L, Glatz D, Raithel J, Lilje B, Rapin N, Bagger FO, Jørgensen M, Andersen PR, Bertin N, Rackham O, Burroughs AM, Baillie JK, Ishizu Y, Shimizu Y, Furuhata E, Maeda S, et al: An atlas of active enhancers across human cell types and tissues. Nature 2014, 507:455-461.

17. Birnbaum RY, Clowney EJ, Agamy O, Kim MJ, Zhao J, Yamanaka T, Pappalardo Z, Clarke SL, Wenger AM, Nguyen L, Gurrieri F, Everman DB, Schwartz CE, Birk OS, Bejerano G, Lomvardas S, Ahituv N: Coding exons function as tissue-specific enhancers of nearby genes. Genome Res 2012 22:1059-1068.

18. Stergachis AB, Haugen E, Shafer A, Wenqing F, Vernot B, Reynolds A, Raubitschek A, Ziegler S, LeProust EM, Akey JM, Stamatoyannopoulos JA: Exonic transcription factor binding directs codon choice and affects protein evolution. Science 2013, 342:1367-1372.

19. Tumpel S, Cambronero F, Sims C, Krumlauf R, Wiedemann LM: A regulatory module embedded in the coding region of Hoxa2 controls expression in rhombomere 2. Proc Natl Acad Sci U S A 2008, 105:20077-20082.

20. Maurano MT, Humbert R, Rynes E, Thurman RE, Haugen E, Wang H, Reynolds AP, Sandstrom R, Qu H, Brody J, Shafer A, Neri F, Lee K, Kutyavin T, Stehling-Sun S, Johnson AK, Canfield TK, Giste E, Diegel M, Bates D, Hansen RS, Neph S, Sabo PJ, Heimfeld S, Raubitschek A, Ziegler S, Cotsapas C, Sotoodehnia N, Glass I, Sunyaev SR et al.: Systematic localization of common disease-associated variation in regulatory DNA. Science 2012, 337:1190-1195.

21. Ernst J, Kheradpour P, Mikkelsen TS, Shoresh N, Ward LD, Epstein CB, Zhang X, Wang L, Issner R, Coyne M, Ku M, Durham T, Kellis M, Bernstein BE: Mapping and analysis of chromatin state dynamics in nine human cell types. Nature 2011, 473:43-49.

22. Trynka G, Sandor C, Han B, Xu H, Stranger BE, Liu XS, Raychaudhuri S: Chromatin marks identify critical cell types for fine mapping complex trait variants. Nat Genet 2013, 45:124-130.

23. Pasquali L, Gaulton KJ, Rodriguez-Segui SA, Mularoni L, Miguel-Escalada I, Akerman I, Tena JJ, Morán I, Gómez-Marín C, van de Bunt M, Ponsa-Cobas J, Castro N, Nammo T, Cebola I, García-Hurtado J, Maestro MA, Pattou F, Piemonti L, Berney T, Gloyn AL, Ravassard P, Gómez-Skarmeta JL, Müller F, McCarthy MI, Ferrer J: Pancreatic islet enhancer clusters enriched in type 2 diabetes risk-associated variants. Nat Genet 2014, 46:136-143.

24. Parker SC, Stitzel ML, Taylor DL, Orozco JM, Erdos MR, Akiyama JA, van Bueren KL, Chines PS, Narisu N, Black BL, Visel A, Pennacchio LA, Collins FS, NISC Comparative Sequencing Program, National Institutes of Health Intramural Sequencing Center Comparative Sequencing Program Authors, NISC Comparative Sequencing Program Authors: Chromatin stretch enhancer states drive cell-specific gene regulation and harbor human disease risk variants. Proc Natl Acad Sci U S A 2013, 110:17921-17926.

25. Stitzel ML, Sethupathy P, Pearson DS, Chines PS, Song L, Erdos MR, Welch R, Parker SC, Boyle AP, Scott L, Margulies EH, Boehnke M, Furey TS, Crawford GE, Collins FS, NISC Comparative Sequencing Program: Global epigenomic analysis of primary human pancreatic islets provides insights into type 2 diabetes susceptibility loci. Cell Metab 2010, 12:443-455.

26. Akhtar-Zaidi B, Cowper-Sal-lari R, Corradin O, Saiakhova A, Bartels CF, Balasubramanian D, Myeroff L, Lutterbaugh J, Jarrar A, Kalady MF, Willis J, Moore JH, Tesar PJ, Laframboise T, Markowitz S, Lupien M, Scacheri PC: Epigenomic enhancer profiling defines a signature of colon cancer. Science 2012, 336:736-739.

27. Alcina A, Fedetz M, Fernández Ó, Saiz A, Izquierdo G, Lucas M, Leyva L, García-León JA, Abad-Grau Mdel M, Alloza I, Antigüedad A, Garcia-Barcina
MJ, Vandenbroeck K, Varadé J, de la Hera B, Arroyo R, Comabella M, Montalban X, Petit-Marty N, Navarro A, Otaegui D, Olascoaga J, Blanco Y, Urcelay E, Matesanz F: Identification of a functional variant in the KIF5A-CYP27B1-METTL1-FAM119B locus associated with multiple sclerosis. J Med Genet 2012, 50:25-33.

28. Bauer DE, Kamran SC, Lessard S, Xu J, Fujiwara Y, Lin C, Shao Z, Canver MC, Smith EC, Pinello L, Sabo PJ, Vierstra J, Voit RA, Yuan GC, Porteus MH, Stamatoyannopoulos JA, Lettre G, Orkin SH: An erythroid enhancer of $B C L 11$ A subject to genetic variation determines fetal hemoglobin level. Science 2013, 342:253-257.

29. Miller CL, Anderson DR, Kundu RK, Raiesdana A, Nurnberg ST, Diaz R, Cheng K, Leeper NJ, Chen CH, Chang IS, Schadt EE, Hsiung CA, Assimes TL, Quertermous T: Disease-related growth factor and embryonic signaling pathways modulate an enhancer of TCF21 expression at the $6 \mathrm{q} 23.2$ coronary heart disease locus. PLoS Genet 2013, 9:e1003652.

30. Smemo S, Tena JJ, Kim KH, Gamazon ER, Sakabe NJ, Gomez-Marin C, Aneas I, Credidio FL, Sobreira DR, Wasserman NF, Lee JH, Puviindran V, Tam D, Shen M, Son JE, Vakili NA, Sung HK, Naranjo S, Acemel RD, Manzanares M, Nagy A, Cox NJ, Hui CC, Gomez-Skarmeta JL, Nóbrega MA: Obesity-associated variants within FTO form long-range functional connections with IRX3. Nature 2014, 507:371-375.

31. Harismendy $O$, Notani $D$, Song $X$, Rahim NG, Tanasa B, Heintzman N, Ren B, Fu XD, Topol EJ, Rosenfeld MG, Frazer KA: 9p21 DNA variants associated with coronary artery disease impair interferon- $\gamma$ signalling response. Nature 2011, 470:264-268.

32. Kapoor A, Sekar RB, Hansen NF, Fox-Talbot K, Morley M, Pihur V, Chatterjee S, Brandimarto J, Moravec CS, Pulit SL, Pfeufer A, Mullikin J, Ross M, Green ED, Bentley D, Newton-Cheh C, Boerwinkle E, Tomaselli GF, Cappola TP, Arking DE, Halushka MK, Chakravarti A, QT Interval-International GWAS Consortium: An enhancer polymorphism at the cardiomyocyte intercalated disc protein NOS1AP locus is a major regulator of the QT interval. Am J Hum Genet 2014, 94:854-869.

33. Guenther CA, Tasic B, Luo L, Bedell MA, Kingsley DM: A molecular basis for classic blond hair color in Europeans. Nat Genet 2014, 46:748-752.

34. Pomerantz MM, Ahmadiyeh N, Jia L, Herman P, Verzi MP, Doddapaneni H, Beckwith CA, Chan JA, Hills A, Davis M, Yao K, Kehoe SM, Lenz HJ, Haiman CA Yan C, Henderson BE, Frenkel B, Barretina J, Bass A, Tabernero J, Baselga J, Regan MM, Manak JR, Shivdasani R, Coetzee GA, Freedman ML: The 8q24 cancer risk variant rs6983267 shows long-range interaction with MYC in colorectal cancer. Nat Genet 2009, 41:882-884.

35. Wasserman NF, Aneas I, Nobrega MA: An 8q24 gene desert variant associated with prostate cancer risk confers differential in vivo activity to a MYC enhancer. Genome Res 2010, 20:1191-1197.

36. Tuupanen S, Yan J, Turunen M, Gylfe AE, Kaasinen E, Li L, Eng C, Culver DA Kalady MF, Pennison MJ, Pasche B, Manne U, de la Chapelle A, Hampel H, Henderson BE, Le Marchand L, Hautaniemi S, Askhtorab H, Smoot D, Sandler RS, Keku T, Kupfer SS, Ellis NA, Haiman CA, Taipale J, Aaltonen LA: Characterization of the colorectal cancer-associated enhancer MYC-335 at 8q24: the role of rs67491583. Cancer Genet 2012, 205:25-33.

37. Spieler D, Kaffe M, Knauf F, Bessa J, Tena JJ, Giesert F, Schormair B, Tilch E, Lee H, Horsch M, Czamara D, Karbalai N, von Toerne C, Waldenberger M, Gieger C, Lichtner P, Claussnitzer M, Naumann R, Müller-Myhsok B, Torres M, Garrett L, Rozman J, Klingenspor M, Gailus-Durner V, Fuchs H, Hrabe de Angelis M, Beckers J, Hölter SM, Meitinger T, Hauck SM, et al: Restless legs syndrome-associated intronic common variant in Meis 1 alters enhancer function in the developing telencephalon. Genome Res 2014, 24:592-603.

38. Cowper-Sal lari R, Zhang X, Wright JB, Bailey SD, Cole MD, Eeckhoute J, Moore $\mathrm{JH}$, Lupien M: Breast cancer risk-associated SNPs modulate the affinity of chromatin for FOXA1 and alter gene expression. Nat Genet 2012, 44:1191-1198.

39. Wright JB, Brown SJ, Cole MD: Upregulation of c-MYC in cis through a large chromatin loop linked to a cancer risk-associated single-nucleotide polymorphism in colorectal cancer cells. Mol Cell Biol 2010, 30:1411-1420.

40. Wang S, Wen F, Wiley GB, Kinter MT, Gaffney PM: An enhancer element harboring variants associated with systemic lupus erythematosus engages the TNFAIP3 promoter to influence A20 expression. PLoS Genet 2013, 9:e1003750.

41. Whyte WA, Orlando DA, Hnisz D, Abraham BJ, Lin CY, Kagey MH, Rahl PB, Lee TI, Young RA: Master transcription factors and mediator establish super-enhancers at key cell identity genes. Cell 2013, 153:307-319.

42. Hnisz D, Abraham BJ, Lee TI, Lau A, Saint-Andre V, Sigova AA, Hoke HA, Young RA: Super-enhancers in the control of cell identity and disease. Cell 2013, 155:934-947. 
43. Zhang X, Cowper-Sal lari R, Bailey SD, Moore JH, Lupien M: Integrative functional genomics identifies an enhancer looping to the SOX9 gene disrupted by the 17q24.3 prostate cancer risk locus. Genome Res 2012, 22:1437-1446.

44. Grice EA, Rochelle ES, Green ED, Chakravarti A, McCallion AS: Evaluation of the RET regulatory landscape reveals the biological relevance of a HSCR-implicated enhancer. Hum Mol Genet 2005, 14:3837-3845.

45. Emison ES, McCallion AS, Kashuk CS, Bush RT, Grice E, Lin S, Portnoy ME, Cutler DJ, Green EG, Chakravarti A: A common sex-dependent mutation in a RET enhancer underlies Hirschsprung disease risk. Nature 2005, 434:857-863.

46. Weedon MN, Cebola I, Patch AM, Flanagan SE, De Franco E, Caswell R, Rodríguez-Seguí SA, Shaw-Smith C, Cho CH, Lango Allen H, Houghton JA, Roth CL, Chen R, Hussain K, Marsh P, Vallier L, Murray A, Ellard S, Ferrer J, Hattersley AT, International Pancreatic Agenesis Consortium: Recessive mutations in a distal PTF1A enhancer cause isolated pancreatic agenesis. Nat Genet 2014, 46:61-64.

47. Furniss D, Lettice LA, Taylor IB, Critchley PS, Giele H, Hill RE, Wilkie AO: A variant in the sonic hedgehog regulatory sequence (ZRS) is associated with triphalangeal thumb and deregulates expression in the developing limb. Hum Mol Genet 2008, 17:2417-2423.

48. Lettice $L A$ : Combinatorial effects of multiple enhancer variants in linkage disequilibrium dictate levels of gene expression to confer susceptibility to common traits. Hum Mol Genet 2003, 12:1725-1735.

49. Kioussis D, Vanin $E$, deLange $T$, Flavell RA, Grosveld FG: $\beta$-Globin gene inactivation by DNA translocation in $\gamma \beta$-thalassaemia. Nature 1983, 306:662-666.

50. Semenza GL, Delgrosso K, Poncz M, Malladi P, Schwartz E, Surrey S: The silent carrier allele: $\beta$ thalassemia without a mutation in the $\beta$-globin gene or its immediate flanking regions. Cell 1984, 39:123-128.

51. Boyle AP, Hong EL, Hariharan M, Cheng Y, Schaub MA, Kasowski M, Karczewski KJ, Park J, Hitz BC, Weng S, Cherry JM, Snyder M: Annotation of functional variation in personal genomes using RegulomeDB. Genome Res 2012, 22:1790-1797.

52. Ward LD, Kellis M: HaploReg: a resource for exploring chromatin states, conservation, and regulatory motif alterations within sets of genetically linked variants. Nucleic Acids Res 2012, 40:D930-D934.

53. Coetzee SG, Rhie SK, Berman BP, Coetzee GA, Noushmehr H: FunciSNP: an R/bioconductor tool integrating functional non-coding data sets with genetic association studies to identify candidate regulatory SNPs. Nucleic Acids Res 2012, 40:e139.

54. Khurana E, Fu Y, Colonna V, Mu XJ, Kang HM, Lappalainen T, Sboner A, Lochovsky L, Chen J, Harmanci A, Das J, Abyzov A, Balasubramanian S, Beal K, Chakravarty D, Challis D, Chen Y, Clarke D, Clarke L, Cunningham F, Evani US, Flicek P, Fragoza R, Garrison E, Gibbs R, Gümüs ZH, Herrero J, Kitabayashi N, Kong Y, Lage K, et al: Integrative annotation of variants from 1092 humans: application to cancer genomics. Science 2013, 342:1235587.

55. Sanyal A, Lajoie BR, Jain G, Dekker J: The long-range interaction landscape of gene promoters. Nature 2012, 489:109-113.

56. Jin F, Li Y, Dixon JR, Selvaraj S, Ye Z, Lee AY, Yen CA, Schmitt AD, Espinoza CA, Ren $B$ : A high-resolution map of the three-dimensional chromatin interactome in human cells. Nature 2013, 503:290-294.

57. Li G, Ruan X, Auerbach RK, Sandhu KS, Zheng M, Wang P, Poh HM, Goh Y, Lim J, Zhang J, Sim HS, Peh SQ, Mulawadi FH, Ong CT, Orlov YL, Hong S, Zhang Z, Landt S, Raha D, Euskirchen G, Wei CL, Ge W, Wang H, Davis C, Fisher-Aylor Kl, Mortazavi A, Gerstein M, Gingeras T, Wold B, Sun Y, et al: Extensive promoter-centered chromatin interactions provide a topological basis for transcription regulation. Cell 2012, 148:84-98

58. Zhang Y, Wong CH, Birnbaum RY, Li G, Favaro R, Ngan CY, Lim J, Tai E, Poh HM, Wong E, Mulawadi FH, Sung WK, Nicolis S, Ahituv N, Ruan Y, Wei CL: Chromatin connectivity maps reveal dynamic promoter-enhancer long-range associations. Nature 2013, 504:306-310.

59. Bickmore WA: The spatial organization of the human genome. Ann Rev Genomics Hum Genet 2013, 14:67-84.

60. Williamson I, Eskeland R, Lettice LA, Hill AE, Boyle S, Grimes GR, Hill RE, Bickmore WA: Anterior-posterior differences in HoxD chromatin topology in limb development. Development 2012, 139:3157-3167.

61. Dekker J, Rippe K, Dekker M, Kleckner N: Capturing chromosome conformation. Science 2002, 295:1306-1311.

62. Simonis $M$, Klous $P$, Splinter E, Moshkin $Y$, Willemsen $R$, de Wit E, van Steensel B, de Laat W: Nuclear organization of active and inactive chromatin domains uncovered by chromosome conformation capture-on-chip (4C). Nat Genet 2006, 38:1348-1354.

63. de Wit $E$, de Laat $W$ : A decade of $3 C$ technologies: insights into nuclear organization. Genes Dev 2012, 26:11-24.

64. Sajan SA, Hawkins RD: Methods for identifying higher-order chromatin structure. Ann Rev Genomics Hum Genet 2012, 13:59-82.

65. Panne D: The enhanceosome. Curr Opin Struct Biol 2008, 18:236-242.

66. Thurman RE, Rynes E, Humbert R, Vierstra J, Maurano MT, Haugen E, Sheffield NC, Stergachis AB, Wang H, Vernot B, Garg K, John S, Sandstrom R, Bates D, Boatman L, Canfield TK, Diegel M, Dunn D, Ebersol AK, Frum T, Giste E, Johnson AK, Johnson EM, Kutyavin T, Lajoie B, Lee BK, Lee K, London D, Lotakis D, Neph S, et al: The accessible chromatin landscape of the human genome. Nature 2012, 489:75-82.

67. Shen Y, Yue F, McCleary DF, Ye Z, Edsall L, Kuan S, Wagner U, Dixon J, Lee L, Lobanenkov W, Ren B: A map of the cis-regulatory sequences in the mouse genome. Nature 2012, 488:116-120.

68. Factor DC, Corradin O, Zentner GE, Saiakhova A, Song L, Chenoweth JG, McKay RD, Crawford GE, Scacheri PC, Tesar PJ: Epigenomic comparison reveals activation of "seed" enhancers during transition from naive to primed pluripotency. Cell Stem Cell 2014, 14:854-863.

69. He B, Chen C, Teng L, Tan K: Global view of enhancer-promoter interactome in human cells. Proc Natl Acad Sci U S A 2014, 111:E2191-E2199.

70. Sheffield NC, Thurman RE, Song L, Safi A, Stamatoyannopoulos JA, Lenhard $B$, Crawford GE, Furey TS: Patterns of regulatory activity across diverse human cell types predict tissue identity, transcription factor binding, and long-range interactions. Genome Res 2013, 23:777-788. http://dnase. genome.duke.edu/

71. Fairfax BP, Makino S, Radhakrishnan J, Plant K, Leslie S, Dilthey A, Ellis P, Langford C, Vannberg FO, Knight JC: Genetics of gene expression in primary immune cells identifies cell type-specific master regulators and roles of HLA alleles. Nat Genet 2012, 44:502-510.

72. Raj T, Rothamel K, Mostafavi S, Ye C, Lee MN, Replogle JM, Feng T, Lee M, Asinovski N, Frohlich I, Imboywa S, Von Korff A, Okada Y, Patsopoulos NA, Davis S, McCabe C, Paik HI, Srivastava GP, Raychaudhuri S, Hafler DA, Koller D, Regev A, Hacohen N, Mathis D, Benoist C, Stranger BE, De Jager PL: Polarization of the effects of autoimmune and neurodegenerative risk alleles in leukocytes. Science 2014, 344:519-523.

73. Patwardhan RP, Hiatt JB, Witten DM, Kim MJ, Smith RP, May D, Lee C, Andrie JM, Lee SI, Cooper GM, Ahituv N, Pennacchio LA, Shendure J: Massively parallel functional dissection of mammalian enhancers in vivo. Nat Biotechnol 2012, 30:265-270.

74. Kheradpour P, Ernst J, Melnikov A, Rogov P, Wang L, Zhang X, Alston J, Mikkelsen TS, Kellis M: Systematic dissection of regulatory motifs in 2000 predicted human enhancers using a massively parallel reporter assay. Genome Res 2013, 23:800-811.

75. Shlyueva D, Stampfel G, Stark A: Transcriptional enhancers: from properties to genome-wide predictions. Nat Rev Genet 2014, 15:272-286.

76. Gaulton KJ, Nammo T, Pasquali L, Simon JM, Giresi PG, Fogarty MP, Panhuis TM, Mieczkowski P, Secchi A, Bosco D, Berney T, Montanya E, Mohlke KL, Lieb JD, Ferrer J: A map of open chromatin in human pancreatic islets. Nat Genet 2010, 42:255-259.

77. The ENCODE Project Consortium: Identification and analysis of functional elements in $1 \%$ of the human genome by the ENCODE pilot project. Nature 2007, 447:799-816.

78. The International HapMap Consortium: A second generation human haplotype map of over 3.1 million SNPs. Nature 2007, 449:851-861.

79. The International HapMap 3 Consortium: Integrating common and rare genetic variation in diverse human populations. Nature 2010, 467:52-58.

80. Ongen $\mathrm{H}$, Andersen $\mathrm{CL}$, Bramsen JB, Oster $\mathrm{B}$, Rasmussen $\mathrm{MH}$, Ferreira PG, Sandoval J, Vidal E, Whiffin N, Planchon A, Padioleau I, Bielser D, Romano L, Tomlinson I, Houlston RS, Esteller M, Orntoft TF, Dermitzakis ET: Putative cis-regulatory drivers in colorectal cancer. Nature 2014, 512:87-90.

81. Fairfax BP, Humburg P, Makino S, Naranbhai V, Wong D, Lau E, Jostins L, Plant K, Andrews R, McGee C, Knight JC: Innate immune activity conditions the effect of regulatory variants upon monocyte gene expression. Science 2014, 343:1246949.

82. Claussnitzer M, Dankel SN, Klocke B, Grallert H, Glunk V, Berulava T, Lee H, Oskolkov N, Fadista J, Ehlers K, Wahl S, Hoffmann C, Qian K, Rönn T, Riess H, Müller-Nurasyid M, Bretschneider N, Schroeder T, Skurk T, Horsthemke B, Spieler D, Klingenspor M, Seifert M, Kern MJ, Mejhert N, Dahlman I, Hansson O, Hauck SM, DIAGRAM + Consortium, et al: Leveraging cross-species 
transcription factor binding site patterns: from diabetes risk loci to disease mechanisms. Cell 2014, 156:343-358.

83. Kilpinen H, Waszak SM, Gschwind AR, Raghav SK, Witwicki RM, Orioli A Migliavacca E, Wiederkehr M, Gutierrez-Arcelus M, Panousis NI, Yurovsky A, Lappalainen T, Romano-Palumbo L, Planchon A, Bielser D, Bryois J, Padioleau I, Udin G, Thurnheer S, Hacker D, Core LJ, Lis JT, Hernandez N, Reymond A, Deplancke $B$, Dermitzakis ET: Coordinated effects of sequence variation on DNA binding, chromatin structure, and transcription. Science 2013, 342:744-747.

doi:10.1186/s13073-014-0085-3

Cite this article as: Corradin and Scacheri: Enhancer variants: evaluating

functions in common disease. Genome Medicine 2014 6:85. 